Zbigniew Ogonowski (Warsaw)

\title{
Leibniz and Socinianism
}

During the post-World War II a discovery was made in Leibniz's manuscripts of several up to then unknown documents concerning his interest in Socinianism. Representing an unequal rank, the documents are associated with various stages in Leibniz's life. In chronological order they are: first, a copy, made in Leibniz's handwriting in 1678, of the Latin publication: Symbolum et Antisymbolum Apostolicum... ${ }^{1}$ The Socinian author of this work confronted two comprehensions of Symbolum Apostolicum by comparing in two columns the Socinian conception (to the left) and the Orthodox Christian one (to the right), with a distinct intention to demonstrate the absurdity of the Orthodox credo. Leibniz did not decipher the author's cryptonym: Satis cum zelo purius, which does not pose a puzzle for the contemporary researcher - its author was Samuel Przypkowski (1592-1670), one of the most outstanding Socinian men of letters. ${ }^{2}$ Obviously, Przypkowski's study fascinated Leibniz since he translated it into the French.

More important documents originate from later years. ${ }^{3}$ In about 1706 , Leibniz recorded his detailed comments about the treatise by Andrzej

1 Niedersächsische Landesbibliothek Hanover, LH 1.2.37. I would like to thank the staff of the Landesbibliothek in Hanover for making accessible the Leibniz manuscripts of interest to me as well as for directives and valuable comments about them.

2 Cf. F. S. Bock, Historia Antitrinitariorum, maxime Socinianismi [...], vol. 1, Königsberg and Leipzig, 1776-1784, pp. 673-74.

3 The manuscript of the French translation in Leibniz's handwriting is to be found elsewhere than the Latin version, namely, in a folio no. LH I, 6, No. 3a-b, for example, in a manuscript of a polemic conducted by Leibniz and Wiszowaty about the Holy Trinity (cf. below, note 20). The date of the translation into French has not been marked. 
Wiszowaty: Religio rationalis, published in 1948 by Gaston Grua, albeit so far professionals have ignored the publication. ${ }^{4}$ In 1707 Leibniz initiated a correspondence with Samuel Crell, grandson of the famous Socinian writer, Johannes Crellius, and the last outstanding Socinian man of letters and activist (if the term: 'Socinian' can be applied in relation to the doctrine of this religious thinker, whose views veered from the opinions of classical Socinianism). ${ }^{5}$ The correspondence was discovered by the British scholar Nicholas Jolley, who partly used it in a study I shall discuss later on. ${ }^{6}$ The correspondence is accompanied by a brief document that Jolley did not notice or intentionally bypassed since it was unconnected with the object of his research: Praecipua Capita Christianae theologiae, in quibus Samuel Crellius a Socino dissentit. ${ }^{7}$ Here, Leibniz distinguished the differences between Socinianism in the version proposed by Faustus Socinus and the doctrine formulated by Samuel Crell. The last document, the most interesting and prominent among the above-listed sources, is Leibniz's dissertation written after July 1708 - a detailed analysis of a treatise by Krzysztof Stegmann (ca. 1598-1646): Metaphysica repurgata. ${ }^{8}$ The dissertation in question, which Leibniz called: Ad Christophori Stegmanni metaphysicam repurgatam, was presented in 1975 and preceded by a copious analytical study by the above-mentioned British researcher, N. Jolley. ${ }^{9}$ This publication, regardless of the importance attached to it

The Latin manuscript was used by Leibniz in 1678, as follows from his handwritten note: 'habui A.D. 1678'.

4 G. W. Leibniz, Textes inédits d'après les manuscrits de la Bibliothèque provinciale de Hanovre, ed. by G. Grua, vol. 1, Paris, 1948, pp. 69-72. Grua did not reprint the 82 'axioms' listed by Wiszowaty, which Leibniz copied down literally from the text.

5 On Samuel Crell see Bock, op. cit., vol. 1, pp. 161-203; see also E. M. Wilbur, A History of Unitarianism. Socinianism and its Antecedents, Cambridge, Mass., 1947, pp. 498-99, 576-77.

6 Cf. below, note 9.

7 Niedersächsische Landesbibliothek Hanover, LB r 182.

8 The treatise Metaphysica repurgata (manuscript copy in Hanover, at the Niedersächsische Landesbibliothek, LH, IV I, 9), written in 1635, is the sole systematic presentation of Socinian metaphysics. It gathers and arranges in order the views of the Socinians, presented upon various occasions in their different writings. The author of the treatise, Krzysztof Stegmann the Older, was the younger brother of Joachim Stegmann the Older, one of the leading Socinian polemicists at the turn of the 1620s and rector of the school in Raków during its peak period (1627-1631). On the Stegmann family and its activity in the Socinian movement see Bock, op. cit., vol. 1, pp. 948-66. 9 'An Unpublished Leibniz MS on Metaphysics', Studia Leibnitiana, 7, 1975, 2, pp. 161-76 (introduction by N. Jolley), 176-89 (text by Leibniz). 
by scholars interested in Socinianism, is significant also for more essential reasons: according to Jolley it contains Leibniz's surprising statements, absent in all his published works and concerning the principles of his metaphysics. These opinions, Jolley claimed, are connected with Leibniz's esoteric doctrine, not intended for publication. ${ }^{10} \mathrm{I}$ became acquainted with the above-listed documents while gathering material for a paper, which I intended to prepare for an international session on Socinianism held in Warsaw in 1979. At the time, I became aware that the topic: 'Leibniz and Socinianism', to which I could devote only few pages of my paper ${ }^{11}$, should become the topic of a separate study.

The following article is envisaged as a survey of assorted problems and material. It is my hope that I shall be able to delve more thoroughly into them in a not too distant future.

When we examine the extremely numerous and, as a rule, thick volumes of anti-Socinianism treaties published during the seventeenth century in Central and Western Europe we find it difficult to resist amazement that such great importance was attached at the time to waging a struggle against a science that today is known only to a few specialists. Characteristically, in the opinion of numerous theologians of the period the expulsion of the Socinians from Poland in 1658 did not reduce the threat but, on the contrary, increased it even further. This was the way the issue was perceived in as late as the turn of the seventeenth century. By way of confirmation we may recall only one of multiple opinions, albeit expressed by a person who was regarded not merely as an expert on the theological and philosophical conflicts of the period but also as extremely credible and cautious in passing on information. I have in mind Pierre Bayle and his article about Socinus in: Dictionnaire historique et critique. True, Bayle declared that the sect declined considerably from the time of its expulsion from Poland and its size diminished considerably, but added: 'as regards its visible state'. The following passage deserves to be cited verbatim:

10 Cf. Jolley's remarks in a summary (Zusammenfassung) at the beginning of the article, p. 161, and at the end, p. 176.

11 Paper: 'Der Sozinianismus aus der Sicht der großen philosophischen Doktrinen des 17. Jahrhunderts', to be published in the congress book. The Polish language version of the paper (without footnotes) in Człowiek i Światopogląd, 1980, 7, pp. 22-33. 
There are quite a few men convinced that it has secretly multiplied and is becoming more numerous day by day. Presumably, in this state of things Europe could soon see that it has become Socinian if mighty rulers were to publicly accept this heresy or only order that admission to it would be freed from all the inconveniencies accompanying it. This is the view of a considerable number of disturbed and alarmed people. ${ }^{12}$

Bayle was by no means one of those authors 'disturbed and alarmed' by the phenomenon of Socinianism. On the contrary, he lucidly and realistically assessed the possibilities of the dissemination of the doctrine and thus did not believe that it could at any time become truly dangerous for orthodoxy.

Bayle did not deem that it could be favoured by 'mighty rulers' if only owing to the programme-like pacifism of its followers, at odds with state interests; nor did he claim that the doctrine could have a chance for wider reception among the masses since, he stressed, it was too philosophical and made excessively great demands of its adherents. Bayle maintained that the Socinian system was only capable of leading 'to Pyrrhonism men of science and minds dealing with deliberations and speculations' ${ }^{13}$ Apparently, Leibniz held a rather similar opinion about the dangers of Socinianism. Upon the basis of our information about him it would be difficult to assume that he could have believed even briefly the assurances of theologians claiming that the Socinians posed a real threat to orthodoxy. He held a different view about the possibility of a Socinian impact upon 'minds dealing with speculations', to cite Bayle. Apparently, Leibniz presumed that in this respect the Socinian doctrine could prove to be extremely harmful. Here, he demonstrated astonishing caution and insightfulness. His appraisal of the philosophy of Locke, whom he accused of succumbing to the bearing of 'Socinian metaphysics', is an excellent example. ${ }^{14}$ Another illustration,

12 Dictionnaire historique et critique [...], Amsterdam, 1740, vol. 4, p. 231.

13 ' $[\ldots]$ on peut assurer avec quelque vraisemblance que le Système des Sociniens n'est guère propre à gagner les peuples. Il est propre à conduire au Pyrrhonisme les gens d'étude, et les esprits qui ne s'occupent que d'examen, et que de spéculations', ibid., p. 232, note 1.

14 See N. Jolley, 'Leibniz on Locke and Socinianism', Journal of the History of Ideas, 39, 1978, 2, pp. 233-50. Jolley attempted to explain the way in which one should understand Leibniz's strange statement (in his correspondence with Bierling), namely, that Locke was inclined towards Socinianism. It should be stressed that in this particular case Leibniz had in mind not Locke's theological deliberations but philosophical views contained in An Essay Concerning Human Understanding, that is, reflections close 
originating from the same period, is a proclamation of a battle against the Socinians formulated in the opening fragments of Causa Dei, a treatise conceived as a detailed outline of Théodicée. ${ }^{15}$ The year was already 1710 . It could be said, therefore, that Leibniz, while clearheadedly assessing the laments of theologians about the supposed Socinian threat to the Churches, tended to magnify the significance of the philosophical doctrine of Socinianism. From his viewpoint this approach was justified. Within the range of Christian thought Socinianism in a certain sense competed with the Leibniz doctrine. The point of departure of the Socinians was ostensibly composed of the same premises as those of Leibniz, that is, they claimed that religion should be based on the foundations of the intellect; just like Leibniz, they were spokesmen of tolerance and irenicism and proclaimed the thesis that after the fall the human mind remained unsullied and capable of formulating apt views also as regards religion; finally, Socinianism maintained that human will is free. Ultimately, it reached conclusions identical as those shared by Leibniz, declaring that the thesis that God is good can be justified with convincing intellectual arguments. At the same time, the Socinians inserted into their system theses and concepts at odds with those found in Leibniz's philosophy and shunned by him to such an extent that one should speak of a radical opposition of both doctrines.

Let us try at this point to confront Leibniz's rationalism and that of the Socinians, and then show the enormous differences, which, notwithstanding certain important common premises, separated the theodicy of the Socinians from the one presented and defended by Leibniz.

\section{Ration alis $\mathrm{m}$}

In about 1706 Leibniz wrote down his remarks in a German language version of A. Wiszowaty's treatise: Religio rationalis, ${ }^{16}$ published in 1703. The author of the translation into the German was Johann Gottfried Zeidler, and it was printed not in Amsterdam (as the title page mistakenly

to problems concerning God and the spirit. Admittedly, the ostensibly paradoxical accusations formulated by Leibniz and incriminating Locke's predilection for Socinian metaphysics comprised, in the light of the explanations offered by Jolley, a certain justification; at any rate, we know what Leibniz had in mind while presenting his charge. Nota bene, Jolley discovered the key to solving this puzzle in the above-mentioned (cf. note 9) study by Leibniz about Socinian metaphysics.

15 In $\$ 3$ : 'Magnitudo Dei studiose tuenda est contra Socinianos inprimis, et quosdam Semisocinianos...' Cf. also Jolley, in 'An Unpublished Leibniz MS...', op. cit., p. 162. 16 Cf. above, note 4. 
claims) but in Halle. Zeidler added a foreword, ${ }^{17}$ and encoded Wiszowaty's name in a pseudonym: Arsenius Sophianus, and that of the publisher and author of the foreword (that is, himself) as Synesius Philadelphus.

Religio rationalis, written by Wiszowaty (1608-78) already at the end of his life, is a concise presentation of Socinian views about the relation between reason and faith, an exposé concerning religious rationalism. It must be said that in comparison with the interpretations proposed by Socinianism during the 1630s, that is, its Sturm- und Drangperiode, Wiszowaty's treatise is extremely moderate. By way of example, the author did not embark upon proving that Christian religion does not contain unfathomable truths, as attempted by Joachim Stegmann the Older. On the other hand, Wiszowaty presented, albeit in a conciliatory manner, a classic Socinian stand, and the difference between him and Stegmann, also as regards the secrets of religion, is, as I have tried to document elsewhere, ${ }^{18}$ rather verbal than real.

What was Leibniz's attitude to the Socinian treatise?

Let us start with an interesting detail, although it does not refer to Wiszowaty's treatise as such but to the foreword preceding it and written by Zeidler. The presented theses shocked Leibniz. While defending the right of the individual's independent interpretation of the Holy Writ, Zeidler rejected rationalism. In doing so, he stressed excessive trust in reason, which, after all, is incurably contaminated and from the time of the original fall leads religion into by-ways, that is, the elimination of true dogmas. The attack against Socinian rationalism was, however, applied for tackling the world of clerics and learned men, who, by using false philosophy based on pagan logic and metaphysics, attempted to consolidate their rule over the common man within the Church. Zeidler, therefore, perceived Wiszowaty's treatise predominantly as a manifesto of religious subjectivism, and the publication of the German translation of the treatise was undertaken by no means for the purpose of propagating the Socinian dogma. It should be treated rather as an expression of protest against the institutionalised caste of priests within the Lutheran Church.

17 Here, I base myself on information contained in the (unpublished) introduction by $T$. Namowicz to the translation by Zeidler. The latter text, prepared by the above author, is to reappear in the three-language Religio rationalis. The Latin-German-French edition will be part of the series Wolfenbütteler Forschungen.

18 Z. Ogonowski, Socynianizm a oświecenie. Studia nad myślą filozoficzno-religijną arian w Polsce XVII wieku, Warsaw, 1966, pp. 484-501. 
Leibniz assessed Zeidler's foreword decidedly negatively, in particular the proposed attitude towards rationalism and philosophy, writing that the postulate of rejecting pagan logic and metaphysics was tantamount to the postulate of discarding pagan arithmetic and geometry. The accusation of theologians and philosophers demanding the right to instruct the common man is absurd. This is a state of things concurrent with Nature. Evil does not consist of the fact that the learned try to guide simpletons and instruct them, but of the fact that those who are regarded as learned and teachers are ignorant men deprived of true knowledge. ${ }^{19}$

Leibniz opted for a hostile stance vis à vis the author of the preface, but he wrote about the author of the treatise, who, after all, was a Socinian, with ... recognition and sympathy. Nota bene, Leibniz did not guess that this author was Wiszowaty, with whom he was familiar and conducted a polemic about the Holy Trinity in $1669 .{ }^{20}$ This is infallible proof that he had never read the Amsterdam edition of Religio rationalis from 1648/85.

According to Leibniz the treatise was written brilliantly. The register of basic metaphysical truths proposed by Wiszowaty was excellent, although it would be possible to discover in it also theses that had been included to smuggle in Socinian views. Leibniz illustrated this statement by resorting to examples and, at the same time, setting right the 'heretical' theses proposed by Wiszowaty according the principles of his metaphysics and the spirit of Christian orthodoxy. Alltold, he regarded the author of the

19 Leibniz, Textes inédits..., op. cit., p. 70.

20 In 1665 Wiszowaty, at the time in Manheim, wrote for Baron Beineburg, with whom he conducted disputes about religion, a dissertation De Sancta Trinitate objectiones quaedam. In it, he tried to demonstrate, with the assistance of sylogisms, the absurdity of the dogma of the Holy Trinity. Several years later, Beineburg showed this study to Leibniz. In the spring of 1669 at the latest Leibniz responded with Defensio Trinitatis per nova reperta logica contra [...] epistolam Ariani non incelebris [...]; idem, Philosophische Schriften, vol. 1: 1663-1672, Darmstadt, 1930 [reprint: Berlin, 1990] (Sämtliche Schriften und Briefe, series 6/1) pp. 548-59. The polemic involving Leibniz and Wiszowaty was reprinted several times in the eighteenth century. In 1773 Lessing prepared a particularly interesting (due to the publisher and his commentary) version in the series Zur Geschichte und Literatur. Aus den Schätzen der Herzoglichen Bibliothek zu Wolfenbüttel (2nd ed., vol. 1). On the circumstances in which Leibniz wrote this study aimed against Wiszowaty see P. Wiedeburg, Der junge Leibniz, das Reich und Europa, part 1, Wiesbaden, 1962, pp. 231-32. A logical analysis of the polemic in question: O. Narbutt, 'Sylogizmy Wiszowatego w świetle krytyki Leibniza', Ruch Filozoficzny, 21, 1962/63, 4, pp. 413-16. 
treatise as extremely learned and familiar with excellent literature, and concluded that the treatise should be published again, although Zeidler's foreword must be omitted and all fragments redolent of Socinianism eliminated from the text, thus producing an extremely useful book.

Leibniz's remarks concerning the treatise by Wiszowaty are interesting for many reasons; at this stage, however, we are concerned with just one. Leibniz praised Wiszowaty, whose religious theses he found totally unacceptable, and harshly condemned Zeidler, with whom he shared the same system of dogmas. Reading the comments made by Leibniz one has the impression that both he and Wiszowaty actually represented the same religious attitude, and thus that the contradictions separating them were accidental and concurrence as regards the principles of religious rationalism remains essential.

Reality was quite different. If Leibniz's ideas had been implemented and Wiszowaty's book published according to his recommendation then it would have turned out toto genere different.

Ending his remarks Leibniz compared Wiszowaty's book with the celebrated work by Ludwig Meier, a friend of Spinoza: Philosophia Sacrae Scripturae interpres, ${ }^{21}$ which, published for the first time in 1666 (the next edition, from 1674, appeared together with Tractatus Theologico-Politicus), produced in The Netherlands a tide of protests and heated discussions. The sense of this comparison was probably the assumption that Leibniz regarded Wiszowaty's treatise to be particularly useful for opposing the stand represented by Meier. In other words, Wiszowaty the Socinian was treated as an ally in a battle waged against the excessive radicalism of the Dutch physician. Consequently, it should be noted that in his treatise Meier regarded his only allies (fautores) among the Christians to be... the Socinians and the Arminians. ${ }^{22}$

21 'Es ist vor etliche Vierzig jähre ein buch in Holland in $4^{\circ}$ heraus kommen, genant philosophia scripturae interpres, gegen welche damals viele geschrieben [...]. Dieses buch haben einige dem Spinozae zugeschrieben, es hat es aber gemacht (ein guther freund des Spinozae) Ludwig Meyer medicus zu Amsterdam. Dieses buch waere gegen den Sophianum [that is, against Wiszowaty - Z. O.] zu halten'; Leibniz, Textes inédits..., op. cit., pp. 71-72.

22 Cf. remarks by Meyer in Chapter XVI (pp. 162-63, edition from 1674) on an analysis of the stand represented by the Socinians: 'Hactenus arma in hostes movimus, atque in illorum terras copias nostras produximus [...]. Nunc, parta Victoria, nostratum partium fautores, et cum nobis quidem non in totum, faciendes, attamen a nostra sententia (quantum ex illorum scriptis colligere possumus) non longe abeuntes invisere libet; et cum iis, coronidis loco, conferre, quousque inter nos, et cum jam 
Let us, therefore, try, by comparing the religious rationalism of Socinianism and Leibniz, to consider the course of the border dividing the two stances.

Socinians understood the thesis claiming that religion is to be concurrent with reason to mean that the contents of the revelation in the Holy Scripture cannot contain dogmas contrary to universally recognised norms of rational thought; consequently, such dogmas as the Holy Trinity, redemption and other similar ones, contrary to the principles of 'common sense', that is, the mind of normal persons (scil. whose mind is not handicapped), are not truths revealed by God but a human conceit. Hence they should be relegated from religion.

Leibniz represented a different approach. ${ }^{23}$ The acceptance of such dogmas as the Holy Trinity, the Incarnation, etc., which the Socinians defined as contrary to reason, are not at odds with the directive of rationalism in religion. True, such dogmas are and shall remain incomprehensible for our mind. This is not to say that they are contrary to reason, even in the case of the Holy Trinity. Leibniz was of the opinion that he had demonstrated this lucidly already in his polemic with Wiszowaty in 1669. ${ }^{24}$

In accordance with the tradition existing in Christian theology Leibniz described the truths of the faith, incomprehensible for the mind, as supra rationem, that is, the mysteries of the faith. The formula: 'truth over reason' functions also in Socinian theology and was used in his treatise already by Wiszowaty. What sort of difference is there between those two stands?

Socinianism contains two interfering concepts of 'truth over reason', that is, mysteries, but none concurs with the traditionalistic conceit. First,

devictis hostibus consentiamus aut dissentiamus, et ut omni ex parte nostras res in tuto collocemus, experiri tentareque, num ad nos pertrahi, nobisque conciliari et firmo foedere jungi possint. Sunt autem hi vel Sociniani vel Arminiani, quorum, ut res tota expeditius conficiatur, primo indagabimus opiniones'.

23 Leibniz wrote on such themes extremely often. One of his particularly interesting early writings is Commentatiuncula de judice controversiarum (in idem, Philosophische Schriften, vol. 1, op. cit., pp. 548-59). Among the later works the most important declarations are to be found in an introduction to Théodicée: Discours préliminaire de la conformité de la foi avec la raison, passim, and in Nouveaux essais sur l'entendement humain, Book IV, Chapters 16, 17, and 18.

24 Cf. above, note 20 . 
the mysteries of religion are truths that the human mind is unable to attain independently without help of the Revelation; from the moment one finds out about them from the Revelation one immediately becomes capable of understanding them. An example of such 'truth over reason' was the mystery of Christ redeeming mankind. This truth was unclearly and enigmatically mentioned in assorted fragments of the Old Testament. From the time when Jesus revealed and explained it the truth in question ceased being a mystery. It remained 'over reason' as long as it was not revealed. Secondly, 'truth over reason' in religion is truth that reason might reach independently, that is, without Divine Revelation, but is incapable of understanding to the very end. Even such truth, albeit not completely comprehended, appears to be not only concurrent with reason but in a certain sense necessary. By way of example, this truth proclaims that God is eternal and that there is no beginning. According to Wiszowaty, it is a 'mystery that sometimes appears to people [my emphasis - Z. O.] to be unacceptable; after all, the mind convinces that this is possible; more, that it is necessary for the first cause for all causes'. ${ }^{25}$ Let us note that such 'truth over reason' constitutes the essential contents of natural religion accepted by the majority of deists. This is, therefore, an entirely different conceit of the 'mystery' than the traditionalistic one. It is also the reason why one of the Socinian writers, that is, the already mentioned Joachim Stegmann the Older, arrived at the conclusion that the concept of 'mystery' is unnecessary in religion and the expression 'truth over reason' is inadequate in relation to the contents that it is supposed to denote. After all, such 'truths over reason' exist in natural philosophy and no one claims that they are mysteries. Stegmann thus proposed a thesis that religion does not contain any truths over reason. ${ }^{26}$ This stand, whose content is identical with the one formulated several decades later by John Toland in his famous treatise Christianity not Mysterious (1696), did not become embedded among the Socinians. Later Socinian authors writing about the same theme probably considered it as much too shocking for the Christian world. In this manner, the formula of 'truth over reason' appears once again in treatises by Samuel Przypkowski and Andrzej Wiszowaty, but always in a specifically Socinian meaning.

25 Religio rationalis. O religii zgodnej z rozumem, parallel Latin-Polish text, Warsaw, 1960, pp. 52-53.

26 'Patet ergo nec supra nec contra rationem esse, quae in sacris litteris nobis cognoscenda proponuntur'; De iudice et norma controversiarum fidei, ed. by J. Domański and Z. Ogonowski, Warsaw, 1963 (Biblioteka Pisarzy Reformacyjnych, 4), p. 59. 
It is easy to notice that Leibniz understood the conception of 'truth over reason' in accordance with traditional theology. This allowed him to accept - not as contrary to reason but only as superior to the potential of human comprehension - the mystery of the Holy Trinity and similar mysteries. The fact that they are unfathomable cannot be a reason for their rejection once the view that God revealed them has been accepted. If they are contained within revelation then they are also concurrent with reason: with the infinite reason of God. If this is the case, then they must be concurrent also with the finite human reason (although we do not understand this), since the latter, in its capacity as a particle of the infinite, cannot be contradictory.

Upon the basis of this juxtaposition, rather superficial but sufficient for our purposes, one can already formulate the following conclusion: the religious rationalism of Socinianism differs from that of Leibniz. According to the former, just like in the case of Leibniz, faith concurs with reason, although this statement does not mean the same in both cases.

For the Socinians it expresses (with all the obvious inconsistencies that can be seen at first glance) a primacy of reason over faith. This predominance is expressed in the conviction that all dogmas contrary to the principles of reason cannot come from God, and thus are not some sort of 'mysteries of the faith' but an absurd conceit devised by theologians. It must be stressed - since this is an essential factor - that in such a comparison we always deal with reason comprehended as a natural ability to judge, characteristic for the human intellect.

In the case of Leibniz, the statement about the concurrence of faith and reason is not antagonistic vis à vis the existing dogmatic. Here, one could speak rather of a primacy of tradition over reason (if we understand 'reason' in the way granted to it by the Socinians).

At this stage we intentionally use the expression 'primacy of tradition' and not 'primacy of faith' so as to accentuate that the stand represented by Leibniz (in the way in which we comprehend it) is totally different from the one proclaiming in a programme-like manner the primacy of faith over reason, frequently known as fideism (I shall delve into this topic below).

The efforts pursued by Leibniz do not intend - as in the case of Socinianism - to 'rationalise' religion but to demonstrate that traditional 
dogmas that comprise the very nerve of Christianism are not contradictory to reason and can be accepted without resigning from the principles of rationalism in religion. Although in places this apologetic used a new conceptual apparatus borrowed from Leibniz's philosophy, it followed the track paved by scholastics. Its edge was turned not only against Socinianism and affiliated currents, but to a much greater degree against fideistic currents that succumbing to the pressure of rationalistic critique, in particular Socinianism, accepted fully the outcome of that critique, that is, the thesis that Christian dogmas known as mysteries are contrary to reason. In fideism the acceptance of that thesis was not connected with the conviction that such dogmas, contrary to reason, should be rejected; quite the opposite, they should be believed in contrary to the dictates of reason.

Fideism came in assorted hues, and often theses stressing the irrational nature of religious dogmas were accompanied by the emancipation of ethics and philosophy. At the turn of the seventeenth century, the leading representative of thus comprehended fideism was Pierre Bayle. Recall that Leibniz's Théodicée was a polemic chiefly with the theses formulated by Bayle declaring the invincible contradiction of faith and reason.

The Bayle case is extremely interesting for our topic. As has been documented, Bayle was an excellent expert on Socinianism. ${ }^{27}$ A convincingly justified hypothesis maintained that it was precisely a slow and thorough examination of the doctrine of Socinianism that contributed to a great measure to the crystallization of Bayle's stand on the philosophy of religion. ${ }^{28}$ Having acknowledged that from the point of view of natural reason the Socinian critique of traditional dogmas is irrefutable, Bayle in turn recognized as unacceptable - from the vantage point of the same principles - the positive doctrine proposed by the Socinians. The latter doctrine, he claimed, divergent from the views maintained by the Socinians, cannot be regarded as religio rationalis; on the contrary, it is embroiled in contradictions just as great as the orthodox doctrines. Bayle was convinced that the ambitious undertaking of the Socinians a conciliation of religion with the principles of reason - ended in a total fiasco. No other outcome was possible. Religion - together with its

27 See K. Pomian, 'Piotr Bayle wobec socynianizmu. Przyczynek do kwestii roli socynianizmu w formowaniu się ideologii oświecenia’, Archiwum Historii Filozofii i Myśli Społecznej, 6, 1960: Studia z dziejów ideologii religijnej XVI i XVII w., pp. 101-82. 28 Ibid. 
chief maxims - contains unsolvable antinomies. Religious rationalism is nonsense. This point of view was unacceptable for Leibniz. Defending religious rationalism against Bayle, Leibniz was inclined - to a certain degree - to accept the arguments amassed by the Socinians. Here lies the secret of his high opinion of Wiszowaty's treatise Religio rationalis, which Bayle assessed harshly and even sarcastically already in $1684 .{ }^{29}$

\section{Theodicy}

There is no Socinian treatise on theodicy. Nor is it possible to indicate any sort of Socinian treatise in which this question was distinguished as a theme in itself. One might, however, certainly claim that the idea of theodicy intertwines throughout Socinian theology and philosophy of religion. More: the entire Socinian doctrine can be presented as a sequence of thoughts that can be derived from theodicy as a basic premise. We do not maintain that such a presupposition was a point of departure for the reflections pursued by Socinus in a re-interpretation of Christianism, but it remains indubitable that it played an enormous role in the crystallization of his religious thought: as one of the leading ideas it exerted an impact, perhaps not always lucidly and fully realized, on a further development of the Socinian doctrine.

Let us attempt to show how the sequences of conclusions drawn from theodicy developed consistently in Socinianism.

Here, the cardinal premise is the idea of a good and just God, modeled according to humanistic morality. This demiurge treats people not in accordance with caprices incomprehensible for them, but according to the stand they assume vis à vis good and evil. The criterion that makes it possible to distinguish one from the other (discrimen mali pravique) is engraved on the heart of each human being. Man does not possess an inborn idea of God but does contain inborn moral feeling. ${ }^{30}$ The target of man's activity on Earth is the realisation of moral values. ${ }^{31}$ In a world

29 In an article from September 1684, published in Nouvelles de la République des lettres (P. Bayle, Oeuvres diverses, vol. 1, The Hague, 1737, pp. 132-33).

30 I discuss these motifs of Socinian thought extensively in my book Socynianizm a oświecenie..., op. cit., Chapters I and II, esp. pp. 63-65 and 88-89. See also ibid., pp. 392-95.

31 On this topic cf. esp. statements by J. Crell in Oratio prima: de honestatis natura et fonte, and Oratio secunda: cur nec Moses nec philosophi perfectum virtutem praescribere et constanter urgere potuerint (Bibliotheca Fratrum Polonorum), in idem, Opera, vol. 3-4, pp. 437-47. Cf. also Ethica Christiana, pp. 261a-63b. 
of rational creatures such realisation is possible only in the conditions of an authentic freedom of making decisions as regards the choice of conduct. Without this freedom morality is just as impossible as religion. In that case, we must accept the irrefutable dogma that man has been granted free will.

In the light of those programme-like ascertainments it is possible to explain all the corrections that the Socinians introduced into the theological doctrine of Christianism. Here they are arranged in order:

1. Negation of predestination, which the Socinians regarded as a dogma at odds with justice. The view that God - the most just being - could sentence people to condemnation before they appeared on Earth and even from time immemorial appeared to be the product of an insane mind.

2. Negation of original sin. This dogma leads to the unavoidable conclusion that after the fall of Adam man would be a mere passive instrument in the hands of the Creator. More, it is impossible to reconcile the thesis that God is just with the view that the guilt of a single human couple could encumber all its successors.

3. Negation of the traditional concept of God's grace. The latter is not granted according to the caprice of the Creator but enhances without exception and to an equal degree all those who hear the voice of the Gospel. It depends on them whether they want to heed it or not.

4. Negation of the foreknowledge of God. Since people are endowed with free will it should be accepted that God does not possess absolutely certain knowledge about the free human decisions that are to take place in the future. Otherwise, the freedom of the will - regardless of what theologians say about it - would be sheer fiction.

This view was accompanied by another, which theologians found just as difficult to accept: that time 'exists' in an absolute manner, that is, that its passage is identical for people and God.

5. Negation of redemption. The traditional doctrine maintaining that thanks to His passion Jesus gained God's forgiveness for the sins of all people collides with the principle of justice, for instance, it renders superfluous man's own merits.

6. Universal salvation in Christianity. Ignorance is not a sin as long as it is no fault of man. The majority of Christians won their religious views as if with mother's milk. An absolute condition for salvation, however, is sincere striving towards obeying the moral injunctions of the Gospel. 
7. Negation of eternal infernal punishment. The view that God punishes sins committed in the brief time that is man's life with torment that is to last for eternity is unacceptable. Such expressions as 'eternal fire of damnation' must be interpreted figuratively.

8. Finally, the negation of mysteries in religion. If religion is true, then it must match human reason. Its task is to indicate the path that people should follow to gain salvation, and its purpose is not to train human minds in complicated theological speculations (S. Przypkowski). In that case, it must be - at least as regards basic truths - clear and universally comprehensible even for simple folk. Enlightenment by the Holy Ghost is by no means indispensable for understanding basic dogmas as a sine qua non condition. If this were the case then man's salvation would depend not on the decisions of his own will but on the grace of God. Apparently, the religious rationalism of the Socinians can be deduced from the idea of theodicy.

The acceptance of the premise that man is absolutely free and in his conduct in no way determined by God has led to serious and, one might say, curious consequences in the philosophy of religion. Since God does not know with absolutely certain knowledge the nature of man's free deeds that are to take place in the future, then He must constantly intervene in the course of human history in order to, suitably for a given situation, correct them and adapt them to his plans made centuries ago. Thus God not only exists in time but also acts in time, which means that $\mathrm{He}$ is not an absolutely invariable being. ${ }^{32}$

Even a superficial comparison of those conceptions with the ones presented by Leibniz in Théodicée immediately reveals profound differences.

Let us attempt to inaugurate our confrontation with a common denominator, that is, the stands accepted by both sides: the Socinians and Leibniz.

Both systems assume that God is good and just, and this is the reason why He does not anything that would be not in accord with moral obligations. The consequence of such a premise is the conclusion that punishment and award must be meted and granted according to conduct that must be unrestricted if punishment and award are to be morally acceptable. In other words, it is necessary to regard freedom of the will as an absolute postulate.

32 Cf. remarks by J. Crell in the treatise De Deo et eius attributis, ibid., Chapter De decretis Dei. I discuss this question in greater detail in Socynianizm a oświecenie..., op. cit., Chapter Bóg socynian, pp. 434-52. 
Further on, everything in Leibniz's writings is different.

We shall arrange our confrontation around two points: 1 . Freedom and necessity, and 2 . The eternity of punishment.

1. Contrary to declarations made by the Socinians (and Hobbes) ${ }^{33}$ it is not true that free will cannot be harmonised with divine pre-knowledge, and freedom with necessity. ${ }^{34}$ In order to understand this, one has to be able to distinguish absolute and conditional (that is, hypothetical) necessity. Absolute necessity cannot be overcome, renders all resistance superfluous, and takes place even if one would like to oppose it and make all possible efforts for the sake of that target. This sort of necessity does not refer to actions voluntaires, because they would not have been made if the will to perform them had not preceded and accompanied them. True, they are preceded, but not absolutely; they are predicted under the condition that they will occur as the result of acts of will. Even though it is certain that Peter will do something it is just as certain that he will do so of his own accord and wishing to do so. This is not a case of Peter's voluntary deed (and the ensuing effect) accomplished regardless of what Peter would do or whether he wanted to do it or not. It will take place because Peter does, and will do everything possible so that the deed is performed. The volitive act on the part of Peter is contained in God's prediction of his deed and is its reason.

The necessity accompanying this sort of deed is conditional (or hypothetical) since it is not realized without acts of will, while all absolute necessity that excludes moral assessment is embedded in things themselves, which take place regardless whether Peter wants it or not.

In this manner, free will concurs excellently with God's foreknowledge, which does not restrict human freedom in any way. On the other hand, a conception negating God's foreknowledge and thus questioning one of God's prime attributes: His omniscience, renders God a deformed essence and is a desecration of the idea of the most perfect being. ${ }^{35}$

33 G. W. Leibniz, Reflexions sur l'ouvrage que M. Hobbes a publié en Anglois, de la liberté, de la nécessité et du hazard, in idem, Die philosophischen Schriften, ed. by C. J. Gerhardt, Berlin, 1875-90, vol. 6, p. 390.

34 Leibniz presented this question in an extremely concise and lucid manner in a supplement to Théodicée: Abrégé de la controverse reduite à des arguments en forme (ibid., pp. 380-81) in response to charge III.

35 Cf. accusations directed against the Socinians in Théodicée: Abrégé [...], $\$ 364$ (ibid., pp. 330-31). 
Another sacrilege is the conclusion stemming from this conception, namely, that God acts in time, constantly intervening in the course of events. Such an opinion inevitably results in flagrant anthropomorphisms.

It must be added that at the basis of Leibniz's acute reaction to the two views lay the fact that both attacked the fundamental theses of his philosophy. After all, the latter assumes that the whole course of the history of the world is fully defined and God cannot alter anything. Let us recall this conception in just a few sentences: prior to the creation of the currently existing world God considered all ideas of possible worlds. Comparing them, He chose the best possible models. This decision, however, made by God who with the aid of the powerful word: 'fiat' granted existence to the world, did not change anything in the configuration of things and left them exactly the same as they were in the state of pure potential. It did not alter either their essence nor nature nor even their accidentia - all existed identically the same already in the idea of the possible world.

The view that God can or wants to change anything in the currently existing world leads to the opinion that at the time of creation God made a false decision as regards the selection of a suitable model of the world, which is sheer nonsense.

According to Leibniz, this conception does not violate the freedom of man. That which was free in the possible and still non-existent world remains just as free after God's resolution to bring the world into being. ${ }^{36}$

2. The second point concerns the dispute about the eternal nature of infernal punishment, but its subtext contained - as we shall soon see - an issue essential for Leibniz and connected with the very core of his metaphysics.

Socinians considered the view about eternal infernal punishment as incompatible with the concept of justice. How could God punish finite crime for an infinite time, that is, infinity!

In that case there simply would be no proportion between crime and punishment. This issue became the topic of a special treatise written by Ernest Soner at the beginning of the seventeenth century. ${ }^{37}$

36 Théodicée: Abrégé [...], \$\$ 52, 53 (ibid., pp. 131-32).

37 Demonstratio theologica et philosophica quod aeterna impiorum supplicia non arguant Dei iustitiam, sed potius iniustitiam - a treatise in Latin published for the first time in 1654 in Eleutheropoli (Amsterdam) in a collected work Fausti et Laelii Socini item Ernesti Soneri tractatus aliquot theologici, nunquam antehac in lucem editi, pp. 36-69. A translation into Polish, together with the Latin text, published 
Leibniz was familiar with this treatise and intended to publish it with his preface in which point by point he toppled the arguments proposed by Soner. ${ }^{38}$ In Théodicée, however, he devoted much attention to arguments intent on justifying the correctness of traditional views and demonstrating that the eternity of punishment does not violate the principle of justice; on the contrary, it is concurrent with it. Here, in a compressed form are the most essential points of his argumentation. ${ }^{39}$

First, God forgives only those who improve. He is also capable of distinguishing them from those who show no chance for amendment. Harshness demonstrated towards evil is much more concurrent with perfect justice than falsely comprehended mercy.

Second, argumentation referring to the thesis that crime finite in time cannot cause infinite punishment is simply incorrect. In order to overthrow it, it suffices to declare that the permanence of crime produces the permanence of punishment: the evil shall always remain evil and cannot be extracted from the state of their plight.

Third, the eternity of punishment is evil, but it is necessary evil, making it possible to prevent even greater evil. We often see how whole towns are destroyed and their inhabitants massacred in order to stir horror among others. Such conduct is cruel but sometimes it prevents a great war or the outbreak of a rebellion; in this way a bloodbath contributes to avoiding the spillage of even more blood.

Fourth, even if it were true that, as it is claimed, the number of condemned people exceeds incomparably the redeemed, in the entire cosmos the number of happy creatures indubitably surpasses those who are unhappy.

Finally, the glory and perfection of the happy are incomparably more important than the unhappiness and imperfection of the doomed. ${ }^{40}$

Socinians combined the negation of eternal punishment with eschatology, whose theses inflamed theologians just as strongly. This eschatology

by T. Bieńkowski and L. Szczucki in Archiwum Historii Filozofii i Myśli Społecznej, 1957, 2, pp. 159-99.

38 A foreword by Leibniz, Leibniz von den ewigen Strafen, was published by Lessing in 1773 (together with a copious presentation) in Zur Geschichte und Literatur..., op. cit. See G. E. Lessing, Gesammelte Werke, ed. by P. Rilla, vol. 7, Berlin, 1956, pp. 454-88.

39 Cf. in particular Théodicée: Abrégé [...], \$\$ 133, 266 (Leibniz, Die philosophischen Schriften, vol. 6, op. cit., pp. 186, 275).

40 Théodicée: Abrégé [...], ibid., p. 378. 
assumed that death is man's natural fate. The first man was also mortal by the very nature of things. The sin committed by Adam did not change anything: Adam had to die even if he had not sinned. ${ }^{41}$ It would be impossible to enter the seat of eternal happiness together with one's earthly body subject to the transformation of matter and destructible. At the time of death the body succumbs to a natural process: it gradually disintegrates and enters into relations with other bodies, sometimes those of other people. The resurrection of the bodies that people possessed at the time of their human life on Earth is thus impossible. The resurrection will consist of God granting to redeemed souls new bodies (corpora gloriosa) not subject to spoilage. The condemned will simply be left to their natural fate: they will be subject to personal annihilation. ${ }^{42}$ This eschatology was supported by a rather original 'psychology', naturally in the Aristotelian comprehension of the term, that is, the doctrine of the soul. This was not a doctrine conceived to the very end, and as regards certain details the Socinians represented divergent views, but they agreed about various fundamental questions, that is, those pertaining to eschatology. Here is a brief résumé of this doctrine. The human spirit belongs to the 'species of spirits' together with the spirits of animals, plants and creatures located lower in the hierarchy of beings lesser than men - the good and evil angels. The same 'species of spirits' includes, nota bene, also the most perfect of all, that is, God. The difference between God and other spirits, although inconceivably great, is, after all, only a difference of the degree and not of the species.

All spirits: those of animals, plants, humans and, finally, God, are an expandable substance, spatially limited (!), and thus in a certain sense corporeal albeit incomparably more perfect; ${ }^{43}$ it can be envisaged as gas or steam (Crell and Wiszowaty). Although the human spirit determines man's vegetative and psychic life, without the body with which it is connected it is incapable of performing all its characteristic activities. From the moment when after death it becomes detached from the body it loses feeling and awareness. Actually, it would be difficult to say that it lives in that state. Having been linked with a new gloriosum body, which will take place at the time of the Judgment, there will emerge a new compositum

41 Epitome colloquii Racoviae anno 1601, ed. by L. Szczucki and J. Tazbir, Warsaw, 1966 (Biblioteka Pisarzy Reformacyjnych, 5), Chapter De homine, esp. pp. 45-46.

42 See Chapter De statu mortuorum, ibid., pp. 88-101.

43 See: Crell, De Deo..., op. cit., pp. 37a, 46a, 4b. I discuss this motif in my book Socynanizm a oświecenie..., op. cit., Chapter V, pp. 298-300. 
and the spirit will re-embark upon its psychic functions as if awoken from a state of lethargy (albeit the existence in which it 'continues' after separation from the body resembles more death than lethargy, without however, actually being death). Man will become just the same as he was in his former earthly body.

In the later phases of Socinianism this 'psychology', fashioned earlier, did not succumb to the impact of more recent philosophy. On the contrary, at the end of the 1640s the Socinians embarked - precisely from those positions - upon a polemic with the Cartesian conception of the spirit comprehended as a thinking but non-expandable substance (Wolzogen). ${ }^{44}$

We are well aware of the abhorrence with which Leibniz must have reacted to the Socinian 'philosophy of the spirit'. Leibniz - as a rule cautious in polemics, moderate in formulating condemnations, and inclined to respect also views with which he disagreed - now opted for stronger words. In Ad Christophori Stegmanni metaphysicam unitariorum he wrote:

\footnotetext{
Those wise and learned men who abuse their intellect propose not only some sort of diluted [extenuatam] theology, but also the same philosophy that is almost bereft of the lofty and the sublime [egregium et sublime]. After all, God Himself is reduced here practically to the rank of a creature. Our soul too is depicted as a despicable being that possesses the nature of matter. I believe that they were upright men, far from impiety, but that their theology leads to the theology of Epicure and is even more menacing than the latter. ${ }^{45}$
}

Slightly further on, he added about Krzysztof Stegmann: 'He [Stegmann] contradicts the existence of any sort of non-corporeal substances and claims that there only exist bodies whose nature is either thinner or thicker. Thus, it seems, he renders also God Himself corporeal. Hence, we can see just how miserable is the deity that he devises'. ${ }^{46}$

One has the impression that reading Stegmann's treatise Leibniz was so irritated by the presented views that he did not always try to understand their author. This is obvious predominantly in excessively hurried generalisations about 'the death of the spirit' in the philosophy

44 J. L. Wolzogen, Annotationes in 'Meditationes metaphysicas' Renati Des Cartis. Uwagi do 'Medytacji metafizycznych' René Descartes'a, parallel Polish-Latin text, Warsaw, 1959 (Biblioteka Klasyków Filozofii), Meditation VI, esp. pp. 54, 59, 62-63.

45 An Unpublished Leibniz MS...', op. cit., p. 177, v. 18-22.

46 Ibid., p. 187, v. 358-60. 
of the Socinians and the supposed consequences of this thesis, namely, the impossibility of personal identification on Judgement Day. ${ }^{47}$

Time for a conclusion. We shall hazard the thesis that it would be difficult to match the view about the posthumous annihilation of the condemned with the philosophy officially proclaimed by Leibniz. Quite possibly, this is the prime reason for the fact that this otherwise kindly and upright man so zealously defended the doctrine of eternal infernal torment. After all, his metaphysics assumed that the human spirit is indestructible or - in the words of Leibniz himself - immortal by the very nature of things.

Leibnizian metaphysics collides drastically with the Socinian doctrine of the spirit. It follows from the principal premises of Leibniz's monadology with firm consistency that the human spirit (as all monads) is a non-expandable and thus non-corporeal substance. From this thesis, that is, the absolute indivisibility of the monad, Leibniz concluded about its indestructible nature. ${ }^{48}$

Let us indicate further that time and space, to which the Socinians attributed real existence (slightly similarly as Newton did subsequently), are in Leibniz's philosophy mere entia rationis. ${ }^{49}$

If, finally, we were to recall that the God of the Socinians exists precisely in time and space and, moreover, that His omniscience is limited as regards future events dependent upon human free will - totally at odds with Leibinz's doctrine of previously established harmony - then

47 '[...] periculosa hic [Stegmann] dogmata insinuat, qualia sunt, materiam esse deo coeternam et animas morte annihilari [my emphasis - Z. O.] [...] statuat novos plane homines in resurrectione prodituros quoad corpus et quoad animam. Unde non apparet quomodo ad nos pertineat illorum hominum felicitas aut infelicitas'. True, K. Stegmann accepted (following the example of other Socinian writers) the hypothesis of the 'death of the spirit' but only in such cases when the hypothesis were to be proved true - confirmed by quotations from the Holy Scripture - that man's spirit is composed of two parts: vegetative and thinking, that is, the 'soul'. In accordance with this conception only the former part could be annihilated. Cf. on this topic K. Stegmann, Metaphysica repurgata, 1. 18, with a distinctly formulated hypothesis shared by the author of the treatise.

48 Cf. Die Monadologie, $\$ \$ 1-6$, also $\$ \$ 73,77,82$.

49 'Tempus et spatium sunt quidam ordines rerum existentium universales; secundum quos una res est alia prior vel posterior; aut alteri proprior vel remotior. Non igitur sunt substantiae nec accidentia [as K. Stegmann maintained - Z. O.], sed aliquid ideale, in rerum tamen veritate fundatum'; Ad Christophori Stegmanni metaphysicam unitariorum, in 'An Unpublished Leibniz MS...', op. cit., p. 184, v. 236-40. 
it becomes obvious that Leibniz operated with a vision of the world and God totally at variance with its Socinian counterpart. One could say that it would be difficult to conceive two more opposing visions. At the same time, however, it is also difficult not to admit that in comparison with the impressive vision proposed by Leibniz - a product of an extraordinarily brilliant imagination - the vision devised by the Socinians appears to be modest.

When, however, a comparison is made of both theodicies without their philosophical foundations our assessment must become slightly dissimilar: Leibniz's arguments attempting to prove that the doctrine of the eternity of punishment cannot aggravate the conscience of the humanist in any way seem to be unacceptable. Regardless of the way in which we shall perceive Socinianism - its philosophy and theology - it would be difficult not to admit that its theodicy expresses contents harmonising with the ideals of justice comprehended in a humanistic and humanitarian manner.

Translated by Aleksandra Rodzinska-Chojnowska

First published as: 'Leibniz i socynianizm', Odrodzenie i Reformacja w Polsce, 26, 1981, s. 105-24. 